\section{Java on the brink}

\section{Jared Diamond}

Zoological Researches in Java, and the Neighbouring Islands. By Thomas Horsfield. Oxford University Press: 1990: No pagination. E175, \$350.

"Your industry, sir, in collecting them is praise-worthy in the extreme; and the talent you have shown in arranging them encourages a well-founded hope of much advantage to science being derived from your arrangement and observations on them." This compliment, written by Sir Joseph Banks around 1817, was addressed to an American physician named Thomas Horsfield, who spent 18 years collecting and describing animal and plant specimens ("them") on the Indonesian island of Java. Between 1821 and 1824 , Horsfield published a lavishly illustrated account of 64 Javan bird and mammal species. That rare landmark in Asian zoology has now been reprinted with an introduction by John Bostin that reconstructs Horsfield's journeys - a task made necessary by Horsfield's having ordered the executor of his will to burn all his diaries and field notes.

As an American working in one of the battlegrounds of Far Eastern colonialism, Horsfield profited from all three European powers involved in the struggle. On arriving in Java when it was a Dutch colony, he was hired to survey Java's poisonous and medicinal plants. He was kept on by the British when they defeated the Dutch in 1811, and was rehired by his former employers when Java was returned to Holland in 1816; but he continued to send his collections to London's East India Company Museum, of which he became a curator on leaving Java. His career was advanced by the British colonial administrator Sir Stamford Raffles in many ways, such as by Raffles' seizure and shipment to London of a large zoological collection amassed by French naturalists. Fearing that the French might nevertheless publish first, Raffles prodded Horsfield to beat them to it. The resulting book is interesting as an account of a remarkable fauna, as a developmental stage in the nineteenth-century tradition of illustrated natural-history treatises, and as a document in conservation biology.

With regards to Java's fauna, the word "island" is often coupled with the phrase "faunally impoverished". Java, however, acquired a rich fauna owing to its equatorial location and high mountains (up to 12,000 feet), as well as its land connections to Asia that existed during the Pleistocene epoch, when sea-level was low. Over those now-flooded land bridges, Java man (Homo erectus) walked to Java nearly a million years ago, along with representatives of many other tropical Asian species. Alfred Russel Wallace's observations of these species in Java and Bali, which were absent on nearby Lombok, stimulated him to recognize the world's most striking faunal transition (Wallace's line) and then to formulate the modern science of

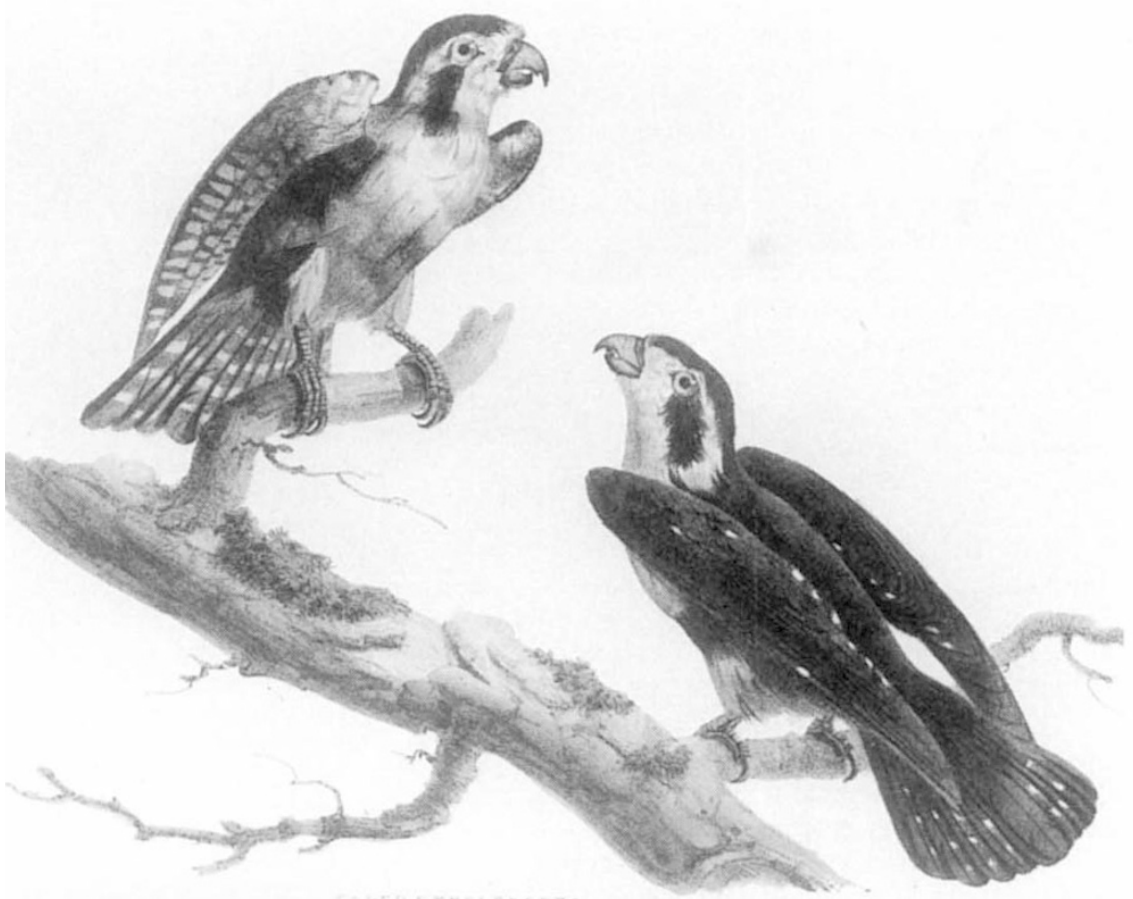

Endangered species - Falco caerulescens, at around six and a half inches long, is thought to be Java's smallest Falcon.

biogeography. Among the Javan species that Horsfield selected for his book are many of these Asian specialities, including a rhinoceros, tapir, gibbon, leafbird and fairy bluebird.

Horsfield's book belongs to the tradition of lavishly illustrated, large-format, limited-edition natural-history volumes that reached their apogee soon afterwards in John James Audubon's The Birds of America and John Gould's many sets of bird books. Today these books are not only rare but expensive, selling at auction for up to millions of dollars. Horsfield's was the second British book to contain hand-coloured lithographs of birds, a practice that became standard with his successors (including Audubon and Gould), who greatly improved on the quality of Horsfield's production.

While a few of Horsfield's bird and mammal illustrations are lively and world, with over 100 million people jammed into an area equivalent to Greece. One-third of Java's resident bird species are endangered, and a dozen of them may already be extinct. The reprinting of Horsfield's book is therefore useful not only to bibliophiles interested in the evolution of illustrated naturalhistory books, but also to conservation biologists for whom Horsfield offers a poignant snapshot of species on the brink of extinction. The reprint is indeed expensive, but the original is simply unavailable except at auction, and then only to millionaires. I hope that presses will now be inspired to reprint the many other unaffordable illustrated naturalhistory books of comparable scientific interest.

Jared Diamond is in the Department of Physiology, University of California Medical School, Los Angeles, California 90024, USA. beautiful, many have unnatural proportions or postures. The text consists mainly of descriptions of anatomy and external appearance, with usually only brief accounts of the behaviour and distribution of the fauna. Lacking is Wallace's interest in broader questions, such as how flightless mammals came to be present on an island.

Instead, Horsfield's lasting value to zoologists rests on his early exploration of a vanishing biota. His collections were the first large, systematic, natural-history collections from Indonesia to reach Europe. He was able to list nearly half of the bird species subsequently recorded from Java. Today, Java is one of the most overpopulated areas of the 